\title{
Virginiamycin, a performance promoter for rabbits
}

\author{
W. VANDAEILE \\ Smith Kline Animal Health Products \\ 19-2I, avenue du Martin-Pêcheur \\ I 7 o Brussels (Belgium)
}

Virginiamycin, a performance promoter of proven value in poultry, pigs and calves has also been tested in rabbits. Data from the literature on safety, metabolism and efficiency in growing rabbits as well as pregnant and nursing does are given.

\section{I. - Efficiency}

a) 6 studies involving nearly 800 rabbits confirmed the value of $20 \mathrm{ppm}$ Virginiamycin in the feed of growing rabbits during the $6-8$ week post weaning period.

The parameters tested were weight gain and feed conversion. There was an average improvement of 5-10 p. Ioo. Statistical analyses of the results will be presented.

b) In 34 does during $7^{8}$ pregnancies where the does reared their own young, addition of $20 \mathrm{ppm}$ $\mathrm{VM}$ to the diet significantly increased litter sizes (on an average $5.28 \mathrm{~g}$ more per young at birth) and growth rate of the young rabbits during the period from birth to 4 weeks of age. Average liveweight gains increased by I I.52 $\mathrm{g}(\mathrm{I} 58.59$ versus 147.07$)$ from birth to 2 weeks and $20 . \mathrm{I} 8 \mathrm{~g}(409.85$ versus 389.67$)$ from 2 weeks to 4 weeks of age.

2. - Safety.

I $50 \mathrm{mg}$ Virginiamycin $/ \mathrm{kg}$ body weight daily per os for 3 weeks and roo-200 ppm daily per os for 15 days produced no ill effects.

\section{3. - Metabolism}

As in poultry, swine and calves, Virginiamycin given as a feed additive until slaughter, leaves no detectable tissue residues. In 4 groups of 1 I rabbits each receiving $0-20-40$ or 80 ppm Virginiamycin in their feed during a 4 week period, all residue values were less than $0 . \mathrm{I}$ microg. per $\mathrm{g}$.

\section{Apparent digestibility of nutrients and energy balance in growing rabbits fed a virginiamycin containing diet}

\author{
M. RIGONI, Clara RUFFINI CASTROVILII, C. CORINO, Claudia NORDIO BALDISSERA \\ Instituto di Zootecnica genevale, Cattedra di Anatomia e Fisiologia degli \\ animali domestici, Facolta di Agravia, Via Celoria 2, Milano (Italy)
}

Addition of $20 \mathrm{ppm}$ of Virginiamycin to a diet for growing rabbits increased the apparent digestibility of fat and protein by 7.8 and 8.3 p. I oo, respectively and also improved the metabolisable energy by 2.9 p. Ioo.

The result did not suggest any influence of the antibiotic on food intake, weight gain, food conversion ratio and protein and fat retention. The effect on net energy was not statistically significant although the mean values in group $\mathrm{V}$ were higher. 